\title{
Salt Tolerance of Southern Baldcypress
}

Cypress-tupelo swamps provide numerous benefits, ranging from wildlife habitat (in south Louisiana, bald eagle nests were found in cypress-tupelo forests $93 \%$ of the time) to forest products (baldcypress lumber is valuable for its rot resistance). These forests also help protect many natural and developed areas by absorbing wind and water energy from hurricanes. After a hurricane, tree survival in cypress-tupelo swamps is much higher than for other hardwood forests in coastal areas.

\section{Threats to Baldcypress}

The volume of baldcypress timber in Louisiana, however, was reduced from 49 million board feet in 1948 to four million board feet in 1977, mostly due to logging. Many cypress swamps logged 30-100 years ago have not regenerated. Also, subsidence and saltwater intrusion have caused the formation of "ghost swamps" or "cypress cemeteries" covering hundreds of hectares (Figs. 1-2).

Flooding from severe hurricanes, submergence associated with local subsidence and sea-level rise, and salinity influences from canals dug in the coastal zones have significantly contributed to the destruction of baldcypress swamps. In addition, many of these areas are now being invaded by exotic and undesirable species of trees that are less able to survive hurricane-force winds and therefore provide less protection to adjacent areas.

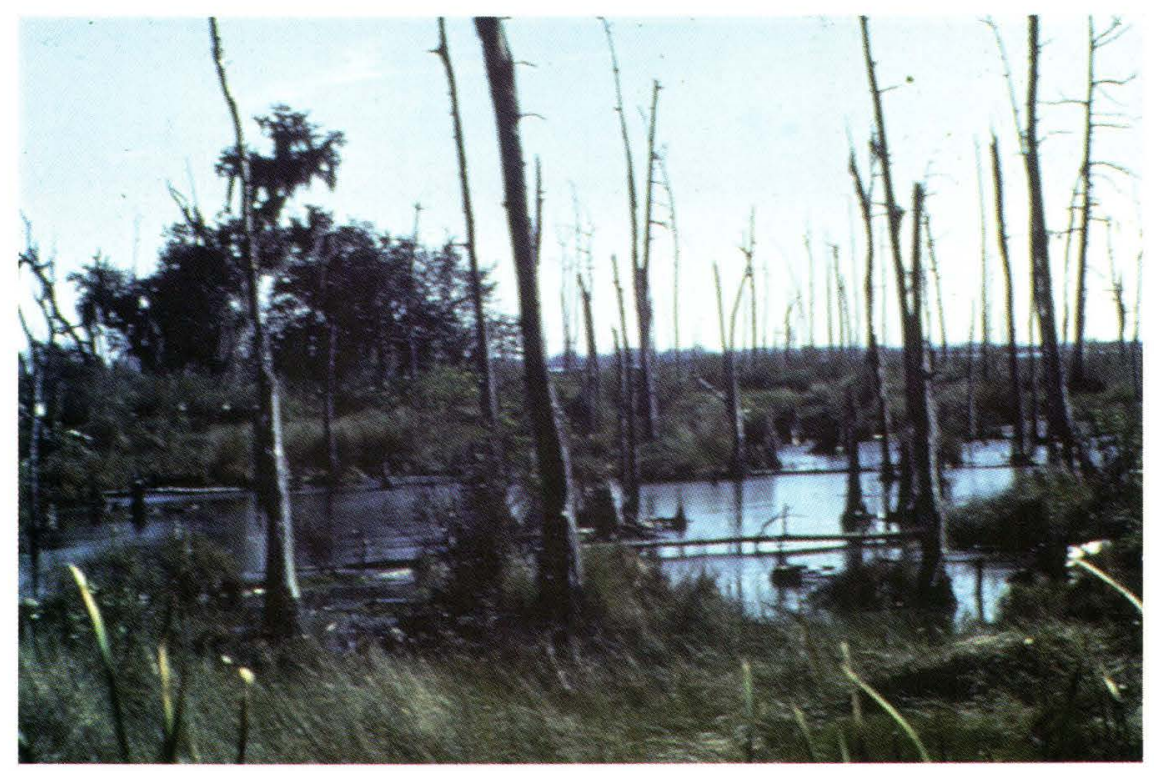

Fig. 1. "Ghost Swamp," Terrebonne Parish, Louisiana.

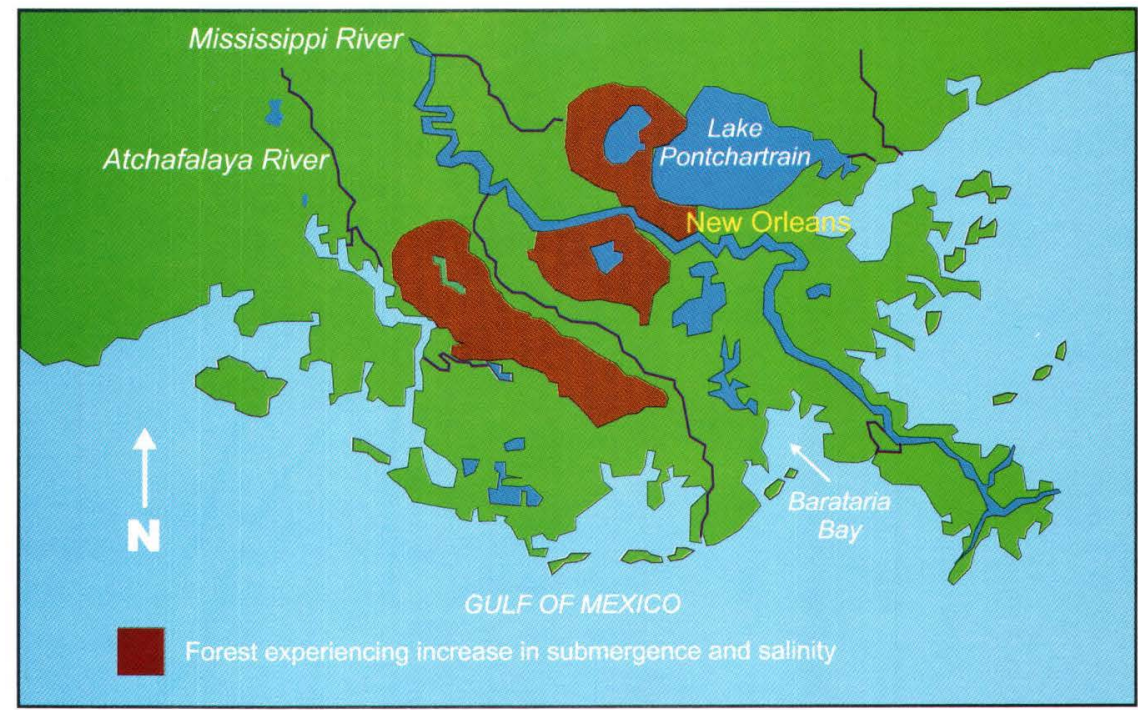

Fig. 2. Coastal Louisiana forest experiencing increase in submergence and salinity. 


\section{Invasive Species}

Research sponsored by the National Wetlands Research Center and conducted by Clemson University scientists compared salinity tolerances of baldcypress and an invasive exotic species, Chinese tallowtree (Sapium sebiferum). Greenhouse experiments were conducted to determine survival, height and diameter growth, and biomass accumulation of the two species when subjected to flooding and various salinity levels of 0,2 , and 10 parts per thousand; seawater averages about 35 parts per thousand. Seedlings of both species survived to the end of the 3 month experiment, except for those flooded with 10 parts per thousand salinity. Baldcypress seedlings died within 2 weeks of flooding in the 10 parts per thousand treatment, while Chinese tallowtree seedlings survived up to 6 weeks. Surviving baldcypress seedlings from the other treatments exhibited more variability in diameter than did Chinese tallowtree, but growth was not significantly affected in either species. However, this study suggests that as salinity and flooding along coastal areas increase, Chinese tallowtree may outcompete baldcypress for available habitat, particularly in seasonally flooded areas.

\section{Salt Tolerance}

Salinity tolerance studies at the National Wetlands Research Center investigate the feasibility of developing saltwater-tolerant baldcypress strains. Greenhouse and field studies identify genetically suitable families of salt- tolerant baldcypress for future plantings. Researchers collected and germinated baldcypress seeds from brackish to freshwater areas in coastal Alabama, Louisiana, and Mississippi (area salinities ranged from 0.1 to 7.5 parts per thousand). A total of 2,700 seedlings was used in the greenhouse study and placed into treatments of 0 , $2,4,6$, and 8 parts per thousand.

Measurements of seedling survival, height, diameter, and physiology were monitored (Fig. 3). Field studies of these same families, planted in saltwater-impacted areas, were undertaken and completed in the autumn of 1996. Measurements of the trees at these sites will continue to be made periodically.

\section{Possible Restoration}

Information from these and other studies indicate that some baldcypress trees have a higher level of salinity and flooding tolerance than the general population of baldcypress. Individuals from mature trees in brackish waters proved to have higher survival and achieved greater growth in saltwater treatments than seedlings from freshwater areas. These tolerances for inundation and salinity are apparently transferred to offspring.

Research such as this may make it possible to restore baldcypress stands in areas impacted by increased salinity and flooding.

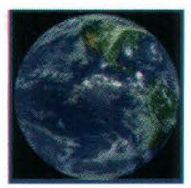

\section{For more information, contact}

James A. Allen

or

Virginia R. Burkett

U.S. Geological Survey

National Wetlands Research Center

700 Cajundome Blvd.

Lafayette, LA 70506

318-266-8636

virginia_burkett@usgs.gov

http://www.nwrc.gov

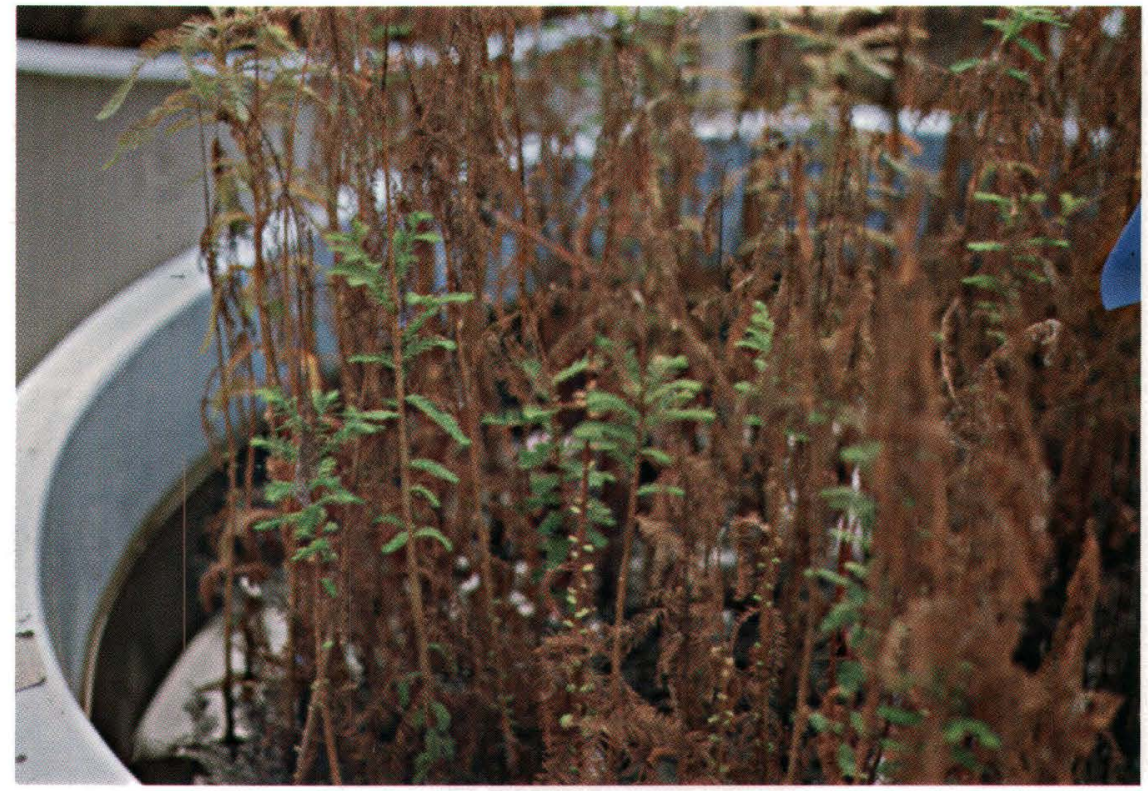

Fig. 3. Measuring baldcypress response in salinity treatments. 